\title{
Protocol of Determining the Effect of Selenium Supplementation on CD4 + T Lymphocyte Count in HIV/AIDS Patients: A Randomized Double Blind Placebo Controlled Trial
}

\author{
Sahar Yousefi ${ }^{1}$, Azar Hadadi ${ }^{2}$, Afshin Ostovar ${ }^{3}$, Behnaz Edalat Noor ${ }^{1}$, Mehrnaz Rasoolinejad ${ }^{4}$, \\ Mahboobeh Haji Abdolbaghi ${ }^{4}$, Hossien Khalili ${ }^{5}$
}

\begin{abstract}
${ }^{1}$ Tehran University of Medical Sciences, Tehran, Iran; ${ }^{2}$ Internal Medicine Ward, Sina Hospital, Iranian Research Center for HIV/AIDS, Tehran University of Medical Sciences, Tehran, Iran; ${ }^{3}$ School of Public Health Knowledge Utilization Research Centre, Tehran University of Medical Sciences, Tehran, Iran; ${ }^{4}$ Department of Infectious Diseases, Imam Khomeini Hospital, Iranian Research Center for HIV/AIDS, Tehran University of Medical Sciences, Tehran, Iran; ${ }^{5}$ Department of Clinical Pharmacy, School of Pharmacy, Tehran University of Medical Sciences, Tehran, Iran.

Email: hadadiaz@tums.ac.ir, afshinostovar@yahoo.com, edalatnoor.behnaz@ymail.com,mehrnaz.rn@gmail.com, saharyousef@rocketmail.com, mahboubeh_hajiabdo@yahoo.com,khalilih@sina.tums.ac.ir
\end{abstract}

Received August 29 $9^{\text {th }}, 2011$; revised October $10^{\text {th }}, 2011$; accepted October $26^{\text {th }}, 2011$.

\begin{abstract}
Background: Acquired immune deficiency syndrome (AIDS) is believed to be both among major epidemics and a critical global health issue. The administration of antiretroviral therapy is recently proposed for all patients with $C D 4+T$ cell count of $\leq 350 /$ ulit in different studies. The accessibility of combination therapy has been restricted due to high costs of drugs, particularly in low and middle income countries. In Iran, according to WHO, drugs were distributed among only $6 \%$ of adults and $4 \%-14 \%$ of children in 2009. Moreover, new strains are created and therefore, resistance to the current medication along with a considerable risk of ART-related toxic adverse effects points out the need for more affordable, effective and safer treatments. The use of antioxidants such as Selenium (Se) has been indicated to be beneficial in these patients. Method: In a double-blind randomized placebo control trial, 100 HIV positive, HAART-receiving patients will be selected from more than 2000 individuals covered under IRCHA (Iranian Referral HIV/AIDS Re- search Centre). They are then randomized to receive daily Se supplement of $200 \mu \mathrm{gr}$ elemental Se and placebo for 6 months. The baseline assessment of the patients who meet the inclusion and exclusion criteria includes doing some lab tests to determine the absolute count of CD4 + T lymphocyte and the plasma levels of Se. The incidence of opportunistic infection will be assessed during the monthly visits in the first six months of the follow-up and the one performed at the end of the $9^{\text {th }}$ month. For evaluating the trend of $C D 4+T$ cells changes, the absolute count of CD4 + T lymphocyte will be measured every 3 months in the $5^{\text {th }}, 8^{\text {th }}$, and $9^{\text {th }}$ visits. The plasma levels of Se will be measured in the final follow-up session and compared with the baseline value.
\end{abstract}

Keywords: Supplementation, HIV, AIDS, Lymphocyte Count, Randomized Clinical Trial

\section{Introduction}

Acquired immune deficiency syndrome (AIDS) that is currently believed to be a critical global health problem [1]. According to WHO statistics (World Health Organization), 33.3 million (31.4 - 35.3 million) people suffered from HIV worldwide in 2009. [2] Until 2008, the cumulative number of people died of AIDS was estimated to be more than 33 million [3]. The unpublished data in Iran until December 2009 show that $92.7 \%$ of the total 20547
HIV-infected individuals are male. From among this population, 2221 have been diagnosed with AIDS and 3543 died secondary to the complications. Recent studies suggest antiretroviral therapy for patients with CD4 $+\mathrm{T}$ cell count $\leq 350 / \mu$ lit [4].

Despite the broader coverage of antiretroviral therapy since 2003 [5], more than 30 million people were diagnosed with HIV in low and middle-income countries in 2009 [6] and from among them, only $36 \%$ with CD4 T cell count $\leq 350 / \mu$ lit received antiretroviral therapy in 
the same year [7].

Iranian the government offers free ART (antiretroviral therapy) to HIV and AIDS patients; the point is that only $6 \%$ of the adults and 4 to $14 \%$ of the children managed to receive the drugs regularly in 2009 [8]. Apart from the toxic effects of ART, the development of new strains of the virus and subsequently resistance to available medications, especially in areas with acceptable coverage of the therapy, indicate that in addition to ART, other alternative therapies are needed in this regard [9].

Many studies have reported that in a highly oxidative state, the progress of HIV infection can be promoted to the host [10]. Thus, treating the patients with antioxidants since early stages of the disease is believed to be beneficial.

Selenium (Se) is a micronutrient with antioxidant and immunoregulatory properties [10]. According to the results of several studies, lower serum Se levels correlates with a smaller total number of CD4 + T cells, more advanced stages of infection and higher rates of mortality caused by HIV [13-21]. Many studies have pointed out the effect of depleted antioxidant agent-like glutathione peroxides- resources which is a result of HIV infection in promoting virus replication and CD4 $+\mathrm{T}$ cell count descent [22-24]. As the infection develops, serum Se concentration diminishes progressively due to several causes including malabsorption caused by chronic infection, infectious diarrhea and HIV-related enteropathy, proteincalorie malnutrition and the inadequate intake of $\mathrm{Se}$ through diets [24,25]. Moreover, HIV contributes to the development of an enzyme with a glutathione peroxidelike structure- $\mathrm{Se}$ is a part of this enzyme structurewhich comprises Se. Hypothetically, virus replication leads to the consumption of Se resources of infected $\mathrm{T}$ cells, through the development of the abovementioned enzyme [26]. There was a positive correlation between serum Se level and CD4 $+\mathrm{T}$ cell count, $\frac{\mathrm{CD} 4}{\mathrm{CD} 8}$ ratio and a negative correlation between this variable and indices of HIV infection progression, i.e. activity of Thymidine kinase and level of $\beta 2$ microglobulin. There was also a positive correlation between serum Se concentration and hematocrit and serum albumin.

In a cross sectional survey conducted in the Iranian research center for HIV/AIDS, Se deficiency (serum Se level $<85 \mu \mathrm{gr} /$ lit) was reported in $38 \%$ of the HIV positive individuals. This is while a healthy male in the control group had significantly lower mean serum Se concentrations [19]. Not many researches have been trials with Se in humans (Table 1). Delmas-Beavieux chose 52 HIV positive patients randomly and supplied them with Se and beta carotene supplements and placebo daily for 12 months. They failed to report any improvement in CD4 $+\mathrm{T}$ cell count, as for the placebo group. However, glutathione levels - an antioxidant factor were significantly higher, whereas malondialdehyde levels - an indicator of lipid peroxidation were significantly lower in both treated groups [20]. In a clinical trial, 19 HIV and AIDS patients received $400 \mu \mathrm{gr}$ Se supplements per day. After 70 days, some subjective improvements in the bowel function, appetite and severity of oral condidiasis as well as a decline in the incidence rate of opportunistic infections were achieved [21]. In another trial, taking Se supplements, which contained lower amounts of elemental Se $(80 \mu \mathrm{gr}$ daily) for two months, significantly improved serum Se levels in HIV and AIDS patients; it, however, had no

Table 1. Summary of clinical trials with Se.

Studies in which administration of Se supplement led to an insignificant improvement in CD4 + T cell count.
Studies in which administration of Se supplement led to a significant improvement in CD4 + T cell count.
1) Delmas-Beavieux supplied $52 \mathrm{HIV}$ patients with $250 \mu$ gr Se or 30 mgr beta carotene for 12 months, no improvement in CD4 $+\mathrm{T}$ cell count was achieved. Gl utathione levels- an antioxidant factor were significantly higher, whereas malondialdehyde levels - an indicator of lipid peroxidation were significantly lower in both treated groups. 2) Cirelli administered $80 \mu \mathrm{gr}$ Se and $25 \mathrm{mgr}$ vit E to $11 \mathrm{HIV}$ patients for two months. No improvement in CD4 + T cell count was achieved. 3) Look supplied 24 HIV patients with 600 mgr N-acetylcystein together with $500 \mu \mathrm{gr}$ Se for 24 weeks, no improvement was achieved in absolute CD $4+\mathrm{T}$ cell count, but there was an increase in $\mathrm{CD}+\mathrm{T}$ cell percentage and CD4 $+\mathrm{T} / \mathrm{CD} 8+\mathrm{T}$ cell ratio.

4) Burbano investigated the effect of $200 \mu \mathrm{gr}$ daily Se supplement on CD4 $+\mathrm{T}$ cell count and hospital admissions of 186 HIV patients. No improvement was achieved in CD4 $+\mathrm{T}$ cell count, but there was a decrease in the rate of patients' hospital admissions due to HIV complications.
Hurwitz investigated the effect of $200 \mu \mathrm{gr}$ daily Se supplement on CD4 + T cell count of 174 HIV patients for 9 months. In the end, there was a significant increase in CD4 $+\mathrm{T}$ cell count. 
effect on CD4 + T cell count, $\frac{\mathrm{CD} 4+\mathrm{T}}{\mathrm{CD} 8+\mathrm{T}}$ ratio, serum albumin, hemoglobin or ESR (Erythrocyte sedimentation rate). Lower amounts of Se, compared to other similar trials, may have contributed to the finding [27]. Similarly, taking $200 \mu$ gr daily Se supplements for 2 years considerably improved Se levels but had no effect on CD4+T cell count. The number of patients with a decline in CD4 $+\mathrm{T}$ cell count of $\leq 50 / \mu$ lit, however, was significantly greater in the placebo treated group $(46 \%$ in contrast with $24 \%$ in Se treated group). Hospital admissions due to opportunistic infections were significantly more common in the placebo group ( $94 \%$ in contrast to $42 \%$ in the $\mathrm{Se}$ group) [28]. A recent trial, stressed that individuals who experienced an increase of at least $26 \mu \mathrm{gr} / \mathrm{lit}$ in serum Se levels following the administration of $200 \mu$ gr daily Se supplements for 9 months (Se responders) were more likely to have a higher CD4 $+\mathrm{T}$ count, but a lower viral load. Despite the fact that the effect of Se supplement on $\mathrm{CD} 4+\mathrm{T}$ cell count was secondary to and a consequence of its impact on viral loud, there was no significant change in CD4 $+\mathrm{T}$ count in Se nonresponders and the placebo group [29]. In another trial, 24 asymptomatic HIV patients were supplied with 1800 mgr N-acetyl cystein along with $500 \mu \mathrm{gr}$ Sodium Selenite daily. In the end, total $\mathrm{CD} 8+\mathrm{T}$ cell count and its proportion decreased and the proportion of $\mathrm{CD} 4+\mathrm{T}$ cell and $\frac{\mathrm{CD} 4+\mathrm{T} \text { cell count }}{\mathrm{CD} 8+\mathrm{T} \text { cell count }}$ ratio increased significantly. No improvement was achieved in CD4 + T cell absolute count. In 9 accidentally chosen patients, the number of HIV RNA copies/ $\mu$ lit did not differ; in $44 \%$ of them, however, this value was steady (no increase) after this time [30]. Considering the results of these studies, more documents regarding the beneficial effects of Se supplementation in HIV + /AIDS patients are needed.

\section{Aim}

Determining the effect of Se supplementation on CD4 + T lymphocyte count in HIV patients

\section{Objectives}

Determining the effects of Se supplementation on

- CD4 + T lymphocyte count in HIV patients;

- Body mass index (BMI) values of HIV patients;

- Hb levels of HIV patients;

- The rate of developing opportunistic infections in HIV patients.

\section{Study Population}

From among 2000 HIV + /AIDS patients covered under the Iranian Research Center for HIV/AIDS (IRCHA), one hundred HIV seropositive HAART-receiving individuals will be selected. IRCHA, located in Imam Khomeini hospital in Tehran is working under the supervision of Tehran University of Medical Sciences. It offers free services such as para-clinical and clinical treatment and consultation to about 2000 HIV positive individuals as well as others at risk of developing HIV or any other sexually transmitted disease.

\section{Recruitment}

Subjects of the study consist of individuals diagnosed with HIV through Western blotting test. Eligible patients meeting the inclusion criteria will be recruited and the others will be excluded (see Table 2). We will recruit 100 HIV infected patients with either sufficient or inadequate serum levels of Se (the deficiency criterion is having serum Selenium levels of $85 \mu \mathrm{g} / \mathrm{dl}$ or lower). A detailed written explanation of the study process, names of individuals and institutions in charge, possible benefits and probable adverse effects of the interventions is given to the participants and additional information would be provided upon request. Informed participants will be asked to sign a written informed consent. After baseline assessment completion and signing the informed consent, all patients will be randomized based on age, sex, HIV infection and AIDS by permuted block randomization with 4 numbers block into two groups, each consisting of $50 \mathrm{HIV}$ positive patients. One group will receive placebo, whereas the other will receive Se supplements. The patients and the researchers are both blinded (see Figure 1).

\section{Baseline Assessments}

In their first visit all participants are required to complete a questionnaire on their demographic information, route

Table 2. Inclusion and exclusion criteria.

\begin{tabular}{ll}
\hline - & \multicolumn{1}{c}{ Inclusion Criteria } \\
\hline - & Age 18 to 60 years \\
- & Confirmed HIV-1 infection with western blotting test \\
- & Receiving HAART treatment \\
- & Pregnancy \\
- & Consumption of any other supplements except for those under \\
- & investigation in the present study \\
- & History of Hypersensitivity reaction to Se supplement \\
- & History of chronic kidney disease or cirrhosis \\
- & Active HBV infection with liver enzyme $>100$ unit/ $\mu$ lit of \\
\hline & Acute or chronic diarrhea or any acute illness with anorexia \\
\hline
\end{tabular}




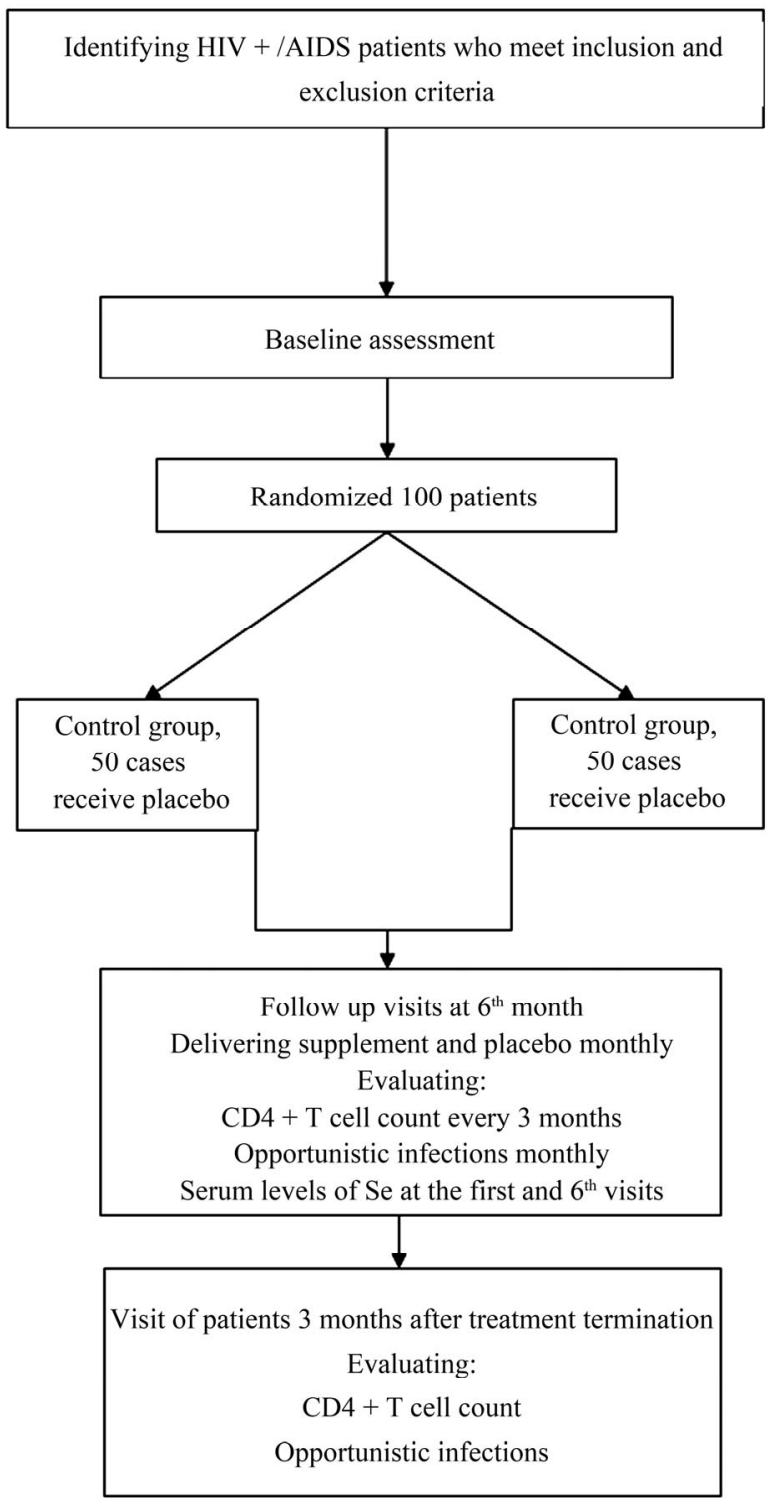

Figure 1. Study flowchart: recruitment \& randomization process of treatment and treatment provision.

of HIV transmission and the number of opportunistic infections during one year prior to the study. A comprehensive physical exam will be performed, a complete medical history will be taken and essential primary lab tests will be performed by the trial clinician in charge (see Table 3).

\section{Intervention}

This double-blind randomized placebo control trial has 2 arms including the supplement and placebo groups. There will be a treatment course for 6 months and supplement capsules which contain $200 \mu$ gr elemental Se or placebo capsules with an inert material will be given to patients for daily administration. Active supplement and placebo capsules will be indistinguishable in colour and taste. Pharmacology faculty laboratory will produce the placebo and supplement capsules. The patients should take one capsule a day and will be recommended to take capsules with a glass of water one hour before lunch. In order to prevent Se toxicity, they will be recommended to take only one capsule per day and not to take two or several capsules together in case they forget to use daily capsules. They will also be asked to bring back the package in the next visit. There will be a 3-month follow up period and a follow up visit in the end.

\section{Follow-Up Assessments}

Altogether, we will perform 9 visits (see Table 4), the first one is the enrolment session in which patients that meet the inclusion and exclusion criteria will be identified and informed. In the second visit, baseline assessment will be performed and the participants will sign the informed consent. 100 patients will be randomized to receive either supplement or placebo. Finally, the patients

Table 3. Baseline parameters.

\begin{tabular}{ll}
\hline & \multicolumn{1}{c}{ Baseline parameters } \\
\hline - & General and life style \\
- & Sex \\
- & Gravity (if female) \\
- & Infection duration \\
- & History of Smoking, alcohol consumption and other kinds of \\
addiction (oral, inhalation) \\
- $\quad$ Rout of infection transmission (History of unsafe sex, using \\
illegal intravenous drugs (IVDU), consumption of blood products, \\
mother to child transmission) \\
- $\quad$ Comprehensive physical examination, medical and drug history \\
- & Lab tests \\
- & complete blood count-differentiation (CBC-diff) \\
- & Kidney function test (BUN/Cr) \\
- & Liver function test (LFT: SGOT, SGPT, ALP) \\
- & HBS Ag \\
- & Anti HBs Ab \\
- & Anti HCV Ab \\
- & Erythrocyte sedimentation rate (ESR) \\
\hline &
\end{tabular}


Table 4. Visits schedule.

\begin{tabular}{|c|c|c|c|c|c|c|c|c|c|}
\hline Visits & $1^{\text {st }}$ Visit & $2^{\text {nd }}$ Visit & $3^{\text {rd }}$ Visit & $4^{\text {th }}$ Visit & $5^{\text {th }}$ Visit & $6^{\text {th }}$ Visit & $7^{\text {th }}$ Visit & $8^{\text {th }}$ Visit & $9^{\text {th }}$ Visit \\
\hline Period & Case finding & Baseline & $\begin{array}{l}\text { End of } 1^{\text {th }} \\
\text { month }\end{array}$ & $\begin{array}{l}\text { End of } 2^{\text {nd }} \\
\text { month }\end{array}$ & $\begin{array}{l}\text { End of } 3^{\text {rd }} \\
\text { month }\end{array}$ & $\begin{array}{l}\text { End of } 4^{\text {th }} \\
\text { month }\end{array}$ & $\begin{array}{c}\text { End of } \\
5^{\text {th }} \text { month }\end{array}$ & $\begin{array}{c}\text { End of } 6^{\text {th }} \\
\text { month }\end{array}$ & End of $9^{\text {th }}$ month \\
\hline \multicolumn{10}{|l|}{ Inclusion \& Exclusion criteria } \\
\hline \multicolumn{10}{|l|}{ Education } \\
\hline \multicolumn{10}{|l|}{ Inform consent } \\
\hline \multicolumn{10}{|l|}{ Medical history } \\
\hline \multicolumn{10}{|l|}{ Physical exam } \\
\hline \multicolumn{10}{|l|}{ Questionnaire } \\
\hline \multicolumn{10}{|l|}{ Lab tests } \\
\hline \multicolumn{10}{|l|}{$\mathrm{CD} 4+\mathrm{T}$ cell count } \\
\hline \multicolumn{10}{|l|}{ Serum Se level } \\
\hline \multicolumn{10}{|l|}{ Adverse effects } \\
\hline Opportunistic infection & & & & & & & & & \\
\hline
\end{tabular}

will receive the package including $30 \mathrm{Se}$ or placebo capsules with the trial clinician explanation of using the capsules 1 hour before lunch. Then, there will be 5 monthly visits at the end of $1^{\text {st }}, 2^{\text {nd }}, 3^{\text {rd }}, 4^{\text {th }}, 5^{\text {th }}$ and $6^{\text {th }}$ months. All patients will be visited at the end of the $3^{\text {rd }}$ month after intervention termination which will be the $9^{\text {th }}$ visit. During every monthly and follow up visit, the physician in charge will take a brief history of the last month, focusing on the incidence of opportunistic infection and manifestations of supplement toxicity. A goal directed physiccal examination based on the taken history will be performed to evaluate the two subjects mentioned above. Physical examination will also include weight, height and blood pressure measurement. Measuring the absolute count of CD4 + T lymphocyte will be repeated every 3 months at $5^{\text {th }}, 8^{\text {th }}$ and $9^{\text {th }}$ visits in order to evaluate the trend of CD4 $+\mathrm{T}$ cells changes. In the $2^{\text {nd }}$ and $6^{\text {th }}$ visits, we will measure the plasma level of Se and compare it with the initiating value to determine whether there has been any significant changes. Values of hemoglobin and hematocrite will also be measured in the visit.

\section{Measures of Compliance}

The patients will be asked to bring the unused capsules back in the next monthly visit to determine their compliance with taking the drug. The proportion of unused capsules to the total number of the capsules

( $\frac{\text { unused capsuls number }}{\text { total number of capsules }}$ ) will be used as an indicator of the participants' compliance.

\section{Concealment}

This study will be double blinded, implying that both participants and the conductors of the trial (individuals providing the patients with their drugs, those performing physical examinations and taking histories in addition to those in charge of performing lab tests) will be unaware whether each patient is receiving supplements or placebo. In this regard, the placebo that contains inactive material will be indistinguishable from supplements based on their color and taste. Additionally, all drug packages will be randomly coded and the statistical analyzer will be the only informed person.

\section{Conclusions}

The authors hope that this study helps clarifying the effectiveness of Selenium on increasing CD4 + T lymphocyte level in HIV + /AIDS Patients.

\section{Competing Interests}

The authors declare that they have no competing interests.

\section{Ethical Approval}

The trial is approved by the ethics committees of the Tehran University Medical Sciences.

\section{Acknowledgements}

This study is supported by grant of Tehran University of Medical Sciences. The authors would like to thank IRCH Research center and Mrs. Sorati for their help in conducting this study as well as Sina Research Development Center, Mrs Pourmand, Dr. Patrishia Khashayar and Dr. Mehdi Aloosh for editing the manuscript.

\section{Efficacy Assessment}

CD4 + T lymphocytes count: The absolute count of pe- 
ripheral blood CD4 $+\mathrm{T}$ lymphocytes is measured by flowcytometric method

Opportunistic infections: all infectious diseases and malignancies detected in immune compromised individuals like HIV infected individuals and is rare with normal immune system function and is clinically or par clinically diagnosed. In our study, these would be HSV infection, mycobacterial infections, Hairy leukoplakia, oral candidiasis, recurrent bacterial pneumonia, Kaposi's sarcoma and cervical cancer.

BMI: An index which is explained in $\frac{\text { weight }(\mathrm{kg})}{\operatorname{height}(\mathrm{m})^{2}}$,

the measuring accuracy would be 0.01 .

Hemoglobin: Blood tetrapyrrolic protein which carries $\mathrm{O}_{2}$ and is measured in $\mathrm{gr} / \mathrm{dl}$.

\section{REFERENCES}

[1] Understanding HIV/AIDS, Nantional Institute of Allergy and Infectious Diseases.

http://www.niaid.nih.gov/topics/hivaids/understanding/Pa ges/Default.aspx

[2] WHO: Global Summary of AIDS Epidemic, 2009. http://www.who.int/hiv/data/2009_global_summary.png

[3] How HIV Causes AIDS, National Nantional Institute of Allergy and Infectious Diseases.

http://www.niaid.nih.gov/topics/HIVAIDS/Understanding /howHIVCausesAIDS/Pages/howhiv.aspx

[4] S. M. Hammer, J. Eron Jr, P. Reiss, R. T. Schooley, M. A. Thompson, S. Walmsley, P. Cahn, M. A. Fischl, J. M. Gatell and M. S. Hirsch, "Antiretroviral Treatment of Adult HIV Infection: Recommendations of the International AIDS Society-USA Panel," Journal of the American Medical Association, Vol. 300, No. 5, 2008, p. 555. doi:10.1001/jama.300.5.555

[5] WHO: HIV/AIDS.

http://www.who.int/features/qa/71/en/index.html

[6] WHO: Classification of Low- and Middle-Income Countries by Income Level, Epidemic Level, and Geographical UNAIDS, UNICEF and WHO Regions.

http://www.who.int/hiv/data/tuapr2010_annex7.xls

[7] WHO: Treated Patients in Low- and Middle-Income Countries by Income Level, Epidemic Level, and Geographical UNAIDS, UNICEF and WHO Regions. http://www.who.int/hiv/data/tuapr_2010_figures_slideset. pps

[8] WHO: Reported Number of People Receiving Antiretroviral Therapy in Low- and Middle-Income Countries by Sex and by Age, and Estimated Number of Children Receiving and Needing Antiretroviral Therapy and Coverage Percentages, 2009.

http://www.who.int/hiv/data/tuapr2010_annex4.xls

[9] Adherence and Drug Resistance, Nantional Institute of Allergy and Infectious Diseases.

http://www.niaid.nih.gov/topics/HIVAIDS/Understanding /Treatment/Pages/adherence.aspx
[10] L. Patrick, "Nutrients and HIV: Part One-Beta Carotene and Selenium," Alternative Medicine Review: A Journal of Clinical Therapeutic, Vol. 4, No. 6, 1999, p. 403.

[11] K. Schwarz and C. M. Foltz, "Selenium as an Integral Part of Factor 3 against Dietary Necrotic Liver Degeneration," Journal of the American Chemical Society, Vol. 79, No. 12, 1957, pp. 3292-3293. doi:10.1021/ja01569a087

[12] P. R. Hoffmann and M. J. Berry, "The Influence of Selenium on Immune Responses," Molecular Nutrition \& Food Research, Vol. 52, No. 11, 2008, pp. 1273-1280. doi:10.1002/mnfr.200700330

[13] M. P. Look, J. K. Rockstroh, G. S. Rao, K. A. Kreuzer, U. Spengler and T. Sauerbruch, "Serum Selenium Versus Lymphocyte Subsets and Markers of Disease Progression and Inflammatory Response in Human Immunodeficiency Virus-1 Infection," Biological Trace Element Research, Vol. 56, No. 1, 1997, pp. 31-41. doi:10.1007/BF02778982

[14] M. K. Baum, G. Shor-Posner, S. Lai, G. Zhang, H. Lai, M. A. Fletcher, H. Sauberlich and J. B. Page, "High Risk of HIV-Related Mortality is Associated with Selenium Deficiency," Journal of Acquired Immune Deficiency Syndromes, Vol. 15, No. 5, 1997, p. 370. doi:10.1097/00042560-199708150-00007

[15] R. Kupka, G. I. Msamanga, D. Spiegelman, S. Morris, F. Mugusi, D. J. Hunter and W. W. Fawzi, "Selenium Status is Associated with Accelerated HIV Disease Progression among HIV-1-Infected Pregnant Women in Tanzania," The Journal of Nutrition, Vol. 134, No. 10, 2004, p. 2556.

[16] C. B. Stephensen, G. S. Marquis, S. D. Douglas, L. A. Kruzich and C. M. Wilson, "Glutathione, Glutathione Peroxidase, and Selenium Status in HIV-Positive and HIV-Negative Adolescents and Young Adults," The American Journal of Clinical Nutrition, Vol. 85, No. 1, 2007, p. 173.

[17] G. Shor-Posner, M. J. Miguez, L. M. Pineda, A. Rodriguez, P. Ruiz, G. Castillo, X. Burbano, R. Lecusay and M. Baum, "Impact of Selenium Status on the Pathogenesis of Mycobacterial Disease in HIV-1-Infected Drug Users during the Era of Highly Active Antiretroviral Therapy," Journal of Acquired Immune Deficiency Syndromes, Vol. 29, No. 2, 2002, p. 169.

[18] J. Constans, J. L. Pellegrin, C. Sergeant, M. Simonoff, I. Pellegrin, H. Fleury, B. Leng and C. Conri, "Serum Selenium Predicts Outcome in HIV Infection," Journal of Acquired Immune Deficiency Syndromes, Vol. 10, No. 3, 1995, p. 392. doi:10.1097/00042560-199511000-00015

[19] H. Khalili, A. Soudbakhsh, M. Hajiabdolbaghi, S. DashtiKhavidaki, A. Poorzare, A. Saeedi and R. Sharififar, "Nutritional Status and Serum Zinc and Selenium Levels in Iranian HIV Infected Individuals," BMC Infectious Diseases, Vol. 8, No. 1, 2008, p. 165. doi:10.1186/1471-2334-8-165

[20] M. C. Delmas-Beauviaux, E. Peuchant, A. Couchouron, J. Constans, C. Sergeant, M. Simonoff, J. L. Pellegrin, B. Leng, C. Conri and M. Clerc, "The Enzymatic Antioxidant System in Blood and Glutathione Status in Human 
Immunodeficiency Virus (HIV)-Infected Patients: Effects of Supplementation with Selenium or Carotene," American Journal of Clinical Nutrition, Vol. 64, No. 1, 1996, pp. 101-107.

[21] L. Olmsted, G. N. Schrauzer, M. Flores-Arce and J. Dowd, "Selenium Supplementation of Symptomatic Human Immunodeficiency Virus Infected Patients," Biological Trace Element Research, Vol. 20, No. 1, 1989, pp. 59-65. doi:10.1007/BF02919098

[22] P. A. Sandstrom, J. Murray, T. M. Folks and A. M. Diamond, "Antioxidant Defenses Influence HIV-1 Replication and Associated Cytopathic Effects," Free Radical Biology and Medicine, Vol. 24, No. 9, 1998, pp. 1485-1491. doi:10.1016/S0891-5849(98)00023-9

[23] M. Kameoka, T. Kimura and K. Ikuta, "Superoxide Enhances the Spread of HIV-1 Infection by Cell-To-Cell Transmission," FEBS Letters, Vol. 331, No. 1-2, 1993, pp. 182-186. doi:10.1016/0014-5793(93)80322-L

[24] W. Dröge, H. P. Eck, H. Gmünder and S. Mihm, "Requirement for Prooxidant and Antioxidant States in T Cell Mediated Immune Responses-Relevance for the Pathogenetic Mechanism of AIDS?" Journal of Molecular Medicine, Vol. 69, No. 21, 1991, pp. 1118-1122.

[25] B. E. Hurwitz, N. G. Klimas, M. M. Llabre, K. J. Maher, J. S. Skyler, M. S. Bilsker, S. McPherson-Baker, P. J. Lawrence, A. R. LaPerriere and J. M. Greeson, "HIV, Metabolic Syndrome X, Inflammation, Oxidative Stress, and Coronary Heart Disease Risk," Cardiovascular Toxicology, Vol. 4, No. 3, 2004, pp. 303-315.

doi:10.1385/CT:4:3:303
[26] E. W. Taylor, R. G. Nadimpalli and C. S. Ramanathan, "Genomic Structures of Viral Agents in Relation to the Biosynthesis of Selenoproteins," Biological Trace Element Research, Vol. 56, No. 1, 1997, pp. 63-91. doi:10.1007/BF02778984

[27] A. Cirelli, M. Ciardi, C. De Simone, F. Sorice, R. Giordano, L. Ciaralli and S. Costantini, "Serum Selenium Concentration and Disease Progress in Patients with HIV Infection," Clinical Biochemistry, Vol. 24, No. 2, 1991, pp. 211-214. doi:10.1016/0009-9120(91)90601-A

[28] X. Burbano, M. Miquez-Burbano, K. McCollister, G. Zhang, A. Rodriguez, P. Ruiz, R. Lecusay and G. Shor-Posner, "Impact of a Selenium Chemoprevention Clinical Trial on Hospital Admissions of HIV-Infected Participants," HIV Clinical Trials, Vol. 3, No. 6, 2002, pp. 483-491. doi:10.1310/A7LC-7C9V-EWKF-2Y0H

[29] B. E. Hurwitz, J. R. Klaus, M. M. Llabre, A. Gonzalez, P. J. Lawrence, K. J. Maher, J. M. Greeson, M. K. Baum, G. Shor-Posner and J. S. Skyler, "Suppression of Human Immunodeficiency Virus Type 1 Viral Load with Selenium Supplementation," Arch International Medicine, Vol. 167, 2007, pp. 148-154. doi:10.1001/archinte.167.2.148

[30] M. P. Look, J. Rockstroh, G. Rao, S. Barton, H. Lemoch, R. Kaiser, B. Kupfer, T. Sudhop, U. Spengler and T. Sauerbruch, "Sodium Selenite and N-Acetylcysteine in Antiretroviralnaive HIV-1-Infected Patients: A Randomized, Controlled Pilot Study," European Journal of Clinical Investigation, Vol. 28, No. 5, 1998, pp. 389-397. doi:10.1046/j.1365-2362.1998.00301.x 